\title{
Discrepancies between two long-term dietary datasets in the
}

\section{United Kingdom (UK) [version 1; peer review: 2 approved]}

\author{
Kerry G. Smith (D1), Pauline Scheelbeek (iD), Andrew Balmford1, \\ Emma E. Garnett (D) 1,3 \\ ${ }^{1}$ Department of Zoology, University of Cambridge, Cambridge, CB2 3EJ, UK \\ ${ }^{2}$ Centre on Climate Change \& Planetary Health, London School of Hygiene \& Tropical Medicine, London, WC1E 7HT, UK \\ ${ }^{3}$ Cambridge Institute for Sustainability Leadership, University of Cambridge, Cambridge, CB2 1QA, UK
}

V1 First published: 16 Dec 2021, 6:350

https://doi.org/10.12688/wellcomeopenres.17245.1

Second version: 20 Sep 2022, 6:350

https://doi.org/10.12688/wellcomeopenres.17245.2

Latest published: 11 Jan 2023, 6:350

https://doi.org/10.12688/wellcomeopenres.17245.3

\section{Abstract}

Background: Studying dietary trends can help monitor progress towards healthier and more sustainable diets but longitudinal data are often confounded by lack of standardized methods. Two main data sources are used for longitudinal analysis of diets: food balance sheets on food supply (FBS) and household budget surveys on food purchased (HBS).

Methods: We used UK longitudinal dietary data on food supply, provided by the Food and Agriculture Organisation (FAO) (FAO-FBS, 1961-2018), and food purchases, provided by Defra (Defra-HBS, 19422018). We assessed how trends in dietary change per capita compared between FAO-FBS and Defra-HBS for calories, meat and fish, nuts and pulses, and dairy, and how disparities have changed over time.

Results: FAO-FBS estimates were significantly higher $(p<0.001)$ than Defra-HBS for calorie intake and all food types, except nuts and pulses which were significantly lower $(p<0.001)$. These differences are partly due to inclusion of retail waste in FAO-FBS data and under-reporting in Defra- HBS data. The disparities between the two datasets increased over time for calories, meat and dairy; did not change for fish; and decreased for nuts and pulses . Between 1961 and 2018, both FAO-FBS and Defra-FBS showed an increase in meat intake $(+11.5 \%$ and $+1.4 \%$, respectively) and a decrease in fish $(-3.3 \%$ and $3.2 \%$, respectively) and dairy intake $(-11.2 \%$ and $-22.4 \%)$. Temporal trends did not agree between the two datasets for calories, and nuts and pulses.

Conclusions: Our finding raises questions over the robustness of both data sources for monitoring UK dietary change, especially when used for evidence-based decision making around health, climate change and sustainability.

\section{Open Peer Review}

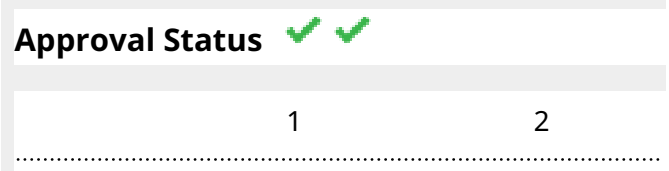

version 3

(revision)

11 Jan 2023

version 2

(revision)

20 Sep 2022

version 1

16 Dec 2021

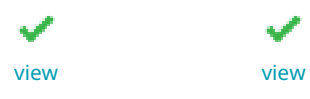

1. Dora Marinova (iD), Curtin University, Perth,

Australia

2. Paul West ID, University of Minnesota,

Minneapolis, USA

Project Drawdown, San Francisco, USA

Any reports and responses or comments on the article can be found at the end of the article. 


\author{
Keywords \\ Dietary change, food balance sheets, household budget survey, UK, \\ longitudinal
}

\title{
Corresponding author: Kerry G. Smith (kerrysmith189@gmail.com)
}

Author roles: Smith KG: Conceptualization, Data Curation, Formal Analysis, Investigation, Methodology, Project Administration, Software, Validation, Visualization, Writing - Original Draft Preparation, Writing - Review \& Editing; Scheelbeek P: Conceptualization, Funding Acquisition, Investigation, Methodology, Project Administration, Supervision, Visualization, Writing - Review \& Editing; Balmford A: Conceptualization, Funding Acquisition, Investigation, Methodology, Project Administration, Supervision, Visualization, Writing - Review \& Editing; Garnett EE: Conceptualization, Data Curation, Funding Acquisition, Investigation, Methodology, Project Administration, Software, Supervision, Visualization, Writing - Review \& Editing

Competing interests: No competing interests were disclosed.

Grant information: P.S is funded by the Wellcome "Our Planet Our Health Programme" [205200, https://doi.org/10.35802/205200, 216021, https://doi.org/10.35802/216021]. This work was supported by E.E.G.'s Natural Environment Research Council (NERC) studentship [NE/L002507/1] and A.B.'s Royal Society Wolfson Research Merit award. The funders had no role in the conceptualization, decision to publish or preparation of the manuscript.

The funders had no role in study design, data collection and analysis, decision to publish, or preparation of the manuscript.

Copyright: @ 2021 Smith KG et al. This is an open access article distributed under the terms of the Creative Commons Attribution License, which permits unrestricted use, distribution, and reproduction in any medium, provided the original work is properly cited.

How to cite this article: Smith KG, Scheelbeek P, Balmford A and Garnett EE. Discrepancies between two long-term dietary datasets in the United Kingdom (UK) [version 1; peer review: 2 approved] Wellcome Open Research 2021, 6:350

https://doi.org/10.12688/wellcomeopenres.17245.1

First published: 16 Dec 2021, 6:350 https://doi.org/10.12688/wellcomeopenres.17245.1 


\section{Introduction}

Monitoring dietary trends is important for measuring progress towards healthier and more sustainable diets. While several longitudinal monitoring databases exist, a number of challenges limit their usefulness for analysis including scarcity of standardized methods (De Keyzer et al., 2015; Perignon et al., 2017), lack of waste monitoring (Whybrow et al., 2017) and variation in the stages of food production being measured (Bandy et al., 2019; Serra-Majem et al., 2003). Both food balance sheets (FBS) (published by Food and Agriculture Organisation (FAO), hereafter referred to as FAO-FBS) and household budget surveys (HBS) (published by Defra in the United Kingdom (UK), hereafter referred to as Defra-HBS) have been used to approximate trends in consumption over time (for example Grünberger, 2014 and Peng et al., 2015).

FBS measure food consumption from a food supply perspective and considers domestic production, imports and exports. The advantage of FBS over HBS is that they are produced in a standardised format, which facilitates comparison between countries, and the combination of food data with associated statistics on trade and agricultural practices (Balanza et al., 2007; Del Gobbo et al., 2015). However, despite adjustments, FAO (2017) report that these FBS can be incomplete or unreliable due to gaps and inaccuracies in underlying data, and complexities in transforming data from a diverse range of sources into a standardised format. HBS measure food consumption from a food purchase perspective (FAO, 2001). Alongside the HBS published by Defra since 1942, Public Health England and the UK Food Standards Agency have conducted the National Diet and Nutrition Survey since 2008-09 (Public Health England, 2020). Here we use the HBS surveys produced by Defra due to the long time period of their operation (81 years compared to the 13 years of the National Diet and Nutrition Survey), permitting the analysis of long-term temporal trends. The strength of HBS is that data are gathered alongside demographic information, which enables the study of consumption characteristics. FBS and HBS measure food consumption at a different stage of the food supply chain: FBS record the quantity of food that reaches shops and other food outlets, while HBS record the quantity of food that is bought. Because of this, FBS include retail waste in quantity of food supply, whereas HBS do not. Both FBS and HBS estimates include waste at the household level, so overestimate the quantity of food actually eaten. In the UK, $70 \%$ of post-farm-gate waste occurs in households (WRAP, 2021). When conducting HBS, reported food purchases are often less than the actual quantity of food bought due to participants' under-reporting (Mendez et al., 2004; Office for National Statistics, 2016).

To our knowledge, the discrepancies between FBS and HBS for monitoring dietary change have never been quantified for the UK. However, as both data sources play a pivotal role in providing evidence for decision-making, it is important that these discrepancies are mapped, and their implications for evidence generation are known. Findings from studies outside the UK indicate that using only one of these methodologies to assess dietary trends can be highly problematic (Del Gobbo et al., 2015; Serra-Majem et al., 2003), and investigating reasons behind data discrepancies helps to understand their limitations (Benthem de Grave et al., 2020). In this study, we compared time-series FBS data produced by FAO (FAOSTAT, 1961-2018, FAO-FBS) on UK food supply to HBS data produced by Defra (National Food Survey, 1942-2000 and Family Food Module, 2000-2018, Defra-HBS) on UK food purchases to determine to what extent the data sources agree, both on overall calorie intake and specific food groups. We assessed how agreement between FAO-FBS and Defra-HBS has changed between 1961 and 2018 (the most up to date data currently available) and the relevance of differences between FAO-FBS and Defra-HBS for evidence-based decision making.

\section{Methods}

Secondary datasets

FAO-FBS consist of compiled, cleaned and standardised data from national statistics on food supply - the quantity of food available to buy per person. Data for food balance sheets are gathered from a number of sources, including industrial production surveys, estimates based on expert observations and household and expenditure surveys (FAO, 2001). FAO adjusts the basic data to account for biases and inaccuracies in data reporting and estimate missing data. We made no further adjustments to account for data inaccuracies and biases, and used the data as provided by the FAO. FAO updated their methodology in 2014. The primary change was the shift from using 2015 United Nations Development Programme (UNDP) population data (used before 2014) to using updated 2019 UNDP population data (FAO, 2020). As some of the revised population numbers are higher than those used previously this can affect per capita values. Despite this, the methodology of FAO-FBS before and after 2014 is broadly consistent so is treated as a single, continuous dataset. Figure 1a summarises the overall method (FAO, 2001; FAO, 2017; Ritchie \& Roser, 2020). FAO-FBS allows comparison between countries as data are produced in a standardised format on nearly all food products.

We compared these FAO-FBS with Defra-HBS, which consists of three household datasets: The National Food Survey, the adjusted National Food Survey and the Family Food Module. All are HBS that record purchases over time of the quantity of food and drink bought by a household. The National Food Survey and Family Food Module use a stratified random sample (with clustering) of UK households (Defra, 2012). In 2011, 5692 households were sampled. Surveys are spread out throughout the year to ensure seasonal effects are accounted for. Both include a voluntary survey in which purchases of food and drink (after 1992) are recorded over a two-week period. Defra make adjustments to account for sampling bias and non-response bias. We made no further adjustments to account for data inaccuracies and biases, and used the data as provided by Defra. To account for differences between the National Food Survey and the Family Food Module methodology, adjusted quantities of the National Food Survey were produced by Defra for 1974 to 2000 (Defra, 2011). Defra-HBS data 
a)

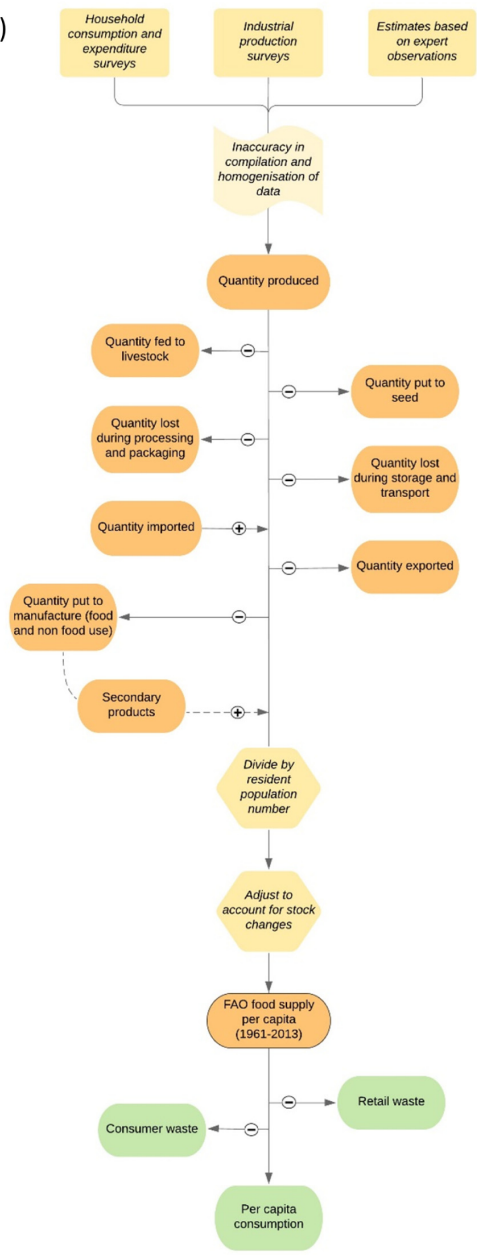

b)

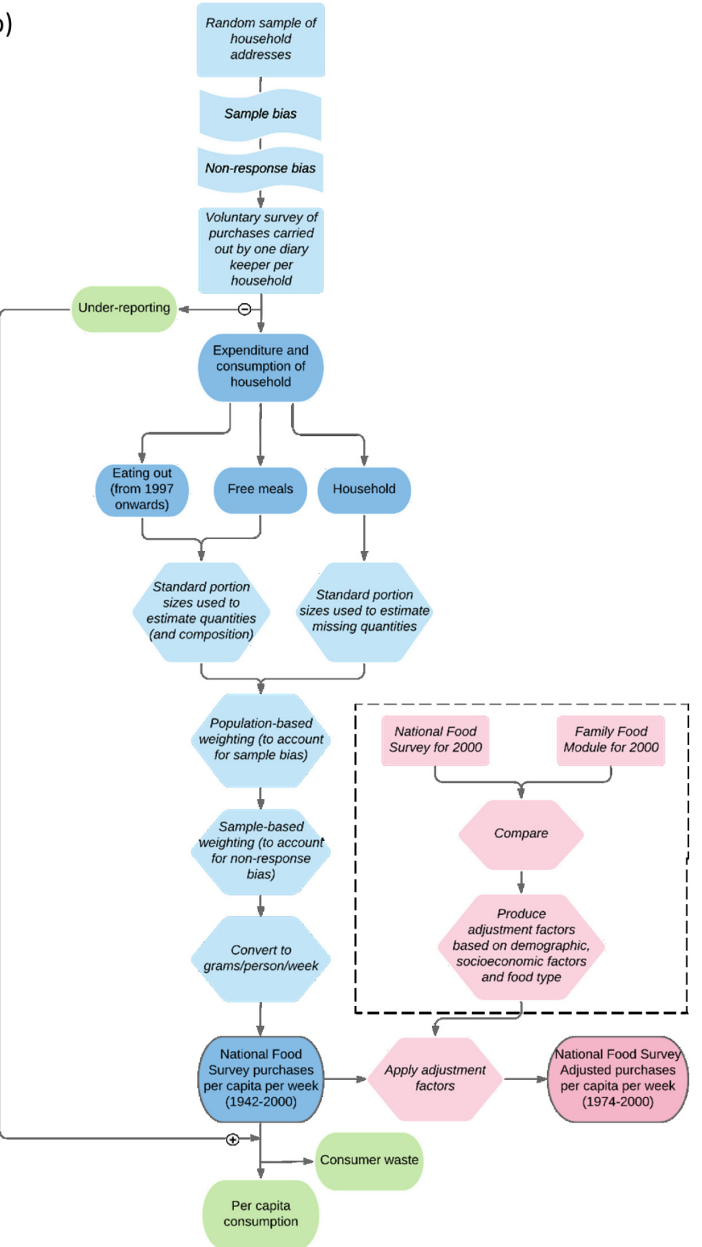

c)

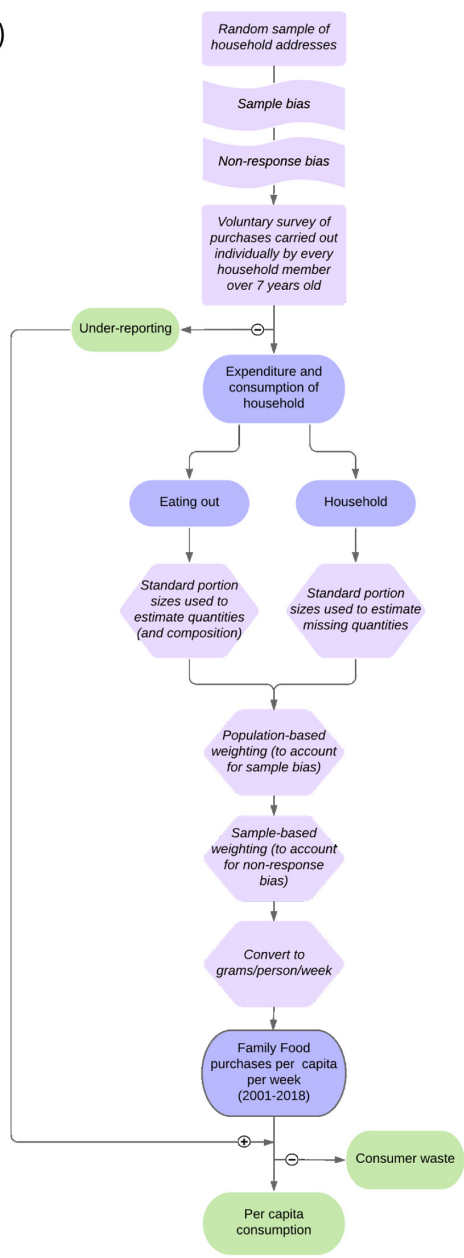

Figure 1. Methodology of a) FAOSTAT (Food and Agriculture Organisation food balance sheets (FAO-FBS)), b) National Food Survey and adjusted National Food Survey (Defra-household budget surveys (Defra-HBS)) and c) Family Food Module (Defra- household budget surveys). Orange (a), blue (b), pink (b) and purple (c) boxes show data values and processes involved in data collection and processing. Green boxes show values not measured. Dark shaded oblongs indicate data values, light shaded oblongs show processes involved in data gathering, hexagons indicate the steps involved in handling data and flags show biases in data gathering.

collection methodologies are summarised in Figure $1 \mathrm{~b}$ and $\mathrm{c}$ (Defra, 2011; Defra, 2012). The difference between Defra-HBS methodologies was deemed small enough to treat all three datasets as continuous. All data on supply and purchases are expressed in grams/capita/day other than calorie intake which is expressed in $\mathrm{kcal} /$ capita/day.

As this study did not involve human subjects and used open-source secondary data which did not include any personal information, an independent ethical review was not required.

The datasets used in this study can be found in the Data availability section (Smith et al., 2021).

\section{Data analysis}

Data analysis was carried out in Excel Version 2108 and $\mathrm{R}$ version 3.6.1 (R Core Team, 2020). Data were converted from $\mathrm{kg} /$ capita/year to $\mathrm{g} /$ capita/day then aggregated according to food types (Table 1). We calculated mean daily per capita supply and production of meat and fish, dairy, nuts and pulses, and calories for each year covered by each data source (Table 1). No data were removed during the analysis. Defra-HBS cheese was converted to milk equivalent by multiplying mass (g) by 10 (the extraction rate from milk to cheese is $10 \%$ in the United Kingdom [FAO, 2000]). Defra-HBS milk and products were converted from millilitres to grams (using the density of cow's milk reported by Cziszter et al., 2012 $\left.\left[1.03 \mathrm{~g} / \mathrm{cm}^{3}\right]\right)$. The food types analysed were chosen as they are produced in categories which are comparable between the two data sources, and provide an indication of changes in total consumption (calorie intake) and protein intake (meat, fish, dairy, nuts and pulses represent the majority of total protein intake in the UK [British Nutrition Foundation, 2018]). Differences in aggregation of food categories between FAOFBS and Defra-HBS makes comparison between some food types challenging. For example, Defra-HBS report purchases of bread, whereas FAO-FBS report supply of wheat and products. As many food groups are produced in aggregated categories, 
Table 1. Methods for estimating household-level consumption of different food types (rows) from Defra (National Food Survey, National Food Survey Adjusted and Family Food Module) and FAO (Food and Agriculture Organisation) sources (columns). Defra data on nuts and pulses purchases are only available from 1974 onwards. *Margarine was excluded from dairy purchases of National Food Survey (Defra). Family food module: hh= household; eo= eating out.

\begin{tabular}{|c|c|c|c|c|}
\hline Food type & $\begin{array}{l}\text { National } \\
\text { Food Survey } \\
\text { (Defra 1942- } \\
\text { 1974) } \\
\text { "Household } \\
\text { consumption } \\
\text { of selected } \\
\text { foods from } \\
1942 \text { to 2000" }\end{array}$ & $\begin{array}{l}\text { National Food Survey } \\
\text { Adjusted } \\
\text { (Defra 1974-2000) } \\
\text { "UK-household } \\
\text { purchases" }\end{array}$ & $\begin{array}{l}\text { Family Food Module } \\
\text { (Defra 2000-2018) } \\
\text { "UK-household } \\
\text { purchases" and “UK- } \\
\text { eating out purchases" }\end{array}$ & $\begin{array}{c}\text { FAO (1961-2018) } \\
\text { (food supply quantity) }\end{array}$ \\
\hline Meat & $\begin{array}{l}\text { Total meat and } \\
\text { meat products } \\
+ \text { Total fish and } \\
\text { fish products }\end{array}$ & $\begin{array}{l}\text { Carcase meat + Non- } \\
\text { carcase meat and meat } \\
\text { products + Fish }\end{array}$ & $\begin{array}{c}\text { Carcase meat }{ }^{\mathrm{hh}}+ \\
\text { Non-carcase meat and } \\
\text { meat products }+ \text { Meat } \\
\text { and meat products } \\
+ \text { Fish }^{\text {hh }}+\text { Fish and fish } \\
\text { products }^{\text {eo }}\end{array}$ & Meat (total) + Fish, seafood (total) \\
\hline Dairy & $\begin{array}{l}\text { Total milk } \\
\text { and cream + } \\
\text { Total cheese + } \\
\quad \text { Butter }\end{array}$ & $\begin{array}{l}\text { Milk products and milk } \\
\text { products excluding } \\
\text { cheese + Cheese }\end{array}$ & $\begin{array}{c}\text { Milk products and milk } \\
\text { products excluding } \\
\text { cheese }^{\text {hh }}+\text { Cheese }^{\text {hh }}+ \\
\text { Milk-based drinks }^{e o}+ \\
\text { Cheese }^{e o}+\text { Yoghurt and } \\
\text { fromage frais } \\
\text { crea }+ \text { Ice } \\
\text { cream }\end{array}$ & Milk- Excluding Butter + Butter, Ghee + Cream \\
\hline $\begin{array}{l}\text { Nuts and } \\
\text { Pulses }\end{array}$ & No data & $\begin{array}{l}\text { Nuts, seeds and peanut } \\
\text { butter }+ \text { Dried pulses } \\
\text { other than air-dryed }+ \\
\text { Other canned beans and } \\
\text { pulses }\end{array}$ & $\begin{array}{c}\text { Nuts, seeds and peanut } \\
\text { butter }^{\text {hh }}+\text { Dried pulses } \\
\text { other than air-dryed } \\
+ \text { Other canned beans } \\
\text { and pulses }{ }^{\text {hh }}+\text { Beans } \\
\text { and pulses }{ }^{\text {eo }}+\text { Nuts and } \\
\text { seeds }^{\text {eo }}\end{array}$ & $\begin{array}{c}\text { Beans + Groundnuts (Shelled Eq) + Nuts and } \\
\text { products + Pulses, other and products + } \\
\text { Soyabeans (available at http://www.fao.org/faostat/ } \\
\text { en/\#data/CC) }\end{array}$ \\
\hline Calories & $\begin{array}{l}\text { Energy (kcal) } \\
\text { Data from } \\
\text { "Household } \\
\text { nutrient data } \\
\text { from } 1940 \text { to } \\
2000-1940- \\
2000 "\end{array}$ & $\begin{array}{l}\text { Energy (kcal) } \\
\text { Data from " } \\
\text { UK - household and } \\
\text { eating out nutrient } \\
\text { intakes (Household_ } \\
\text { intake)" }\end{array}$ & $\begin{array}{l}\text { Energy (kcal) } \\
\text { Data from “ } \\
\text { UK - household and } \\
\text { eating out nutrient } \\
\text { intakes (Total_intake)" }\end{array}$ & $\begin{array}{l}\text { Grand total } \\
\text { (food supply, kcal/capita/day) }\end{array}$ \\
\hline Bovine & Beef and veal & $\begin{array}{c}\text { Beef and veal + Ox liver } \\
+ \text { Corned beef, canned } \\
\text { or sliced }\end{array}$ & $\begin{array}{l}\text { Beef and vealhh }+ \text { Ox } \\
\text { liverhh }^{\text {hi }} \text { Corned beef, } \\
\text { canned or sliced }^{\text {hh }}+ \\
\text { Steak - without sauce } \\
\text { (e.g. braised, sirloin) }\end{array}$ & Bovine Meat \\
\hline Mutton & $\begin{array}{l}\text { Mutton and } \\
\text { lamb }\end{array}$ & $\begin{array}{c}\text { Mutton and lamb + lamb } \\
\text { liver }\end{array}$ & $\begin{array}{c}\text { Mutton and lamb } b^{\text {hh }}+ \\
\text { lambs liverhh }+ \text { Lamb } \\
\text { chops with sauce or } \\
\text { gravy }\end{array}$ & Mutton \& Goat Meat \\
\hline Pork & $\begin{array}{l}\text { Pork, bacon } \\
\text { and ham }\end{array}$ & $\begin{array}{c}\text { Pork + Sausages, } \\
\text { uncooked - pork + } \\
\text { Bacon and ham, cooked } \\
+ \text { Bacon and ham, } \\
\text { uncooked + Pigs liver }\end{array}$ & $\begin{array}{c}\text { Pork }{ }^{\text {hh }}+\text { Sausages, } \\
\text { uncooked - pork } \\
\text { + Bacon and ham, } \\
\text { cooked }^{\text {hh }}+\text { Bacon and } \\
\text { ham, uncooked }^{\text {hh }}+\text { Pigs } \\
\text { liverhh }+ \text { Bacon }^{\text {ho }}+\text { Pork } \\
\text { chops with sauce or }^{\text {ghavy }}+\text { Gammon or } \\
\text { grameo }^{\text {ha }}\end{array}$ & Pigmeat \\
\hline
\end{tabular}




\begin{tabular}{|c|c|c|c|c|}
\hline Food type & $\begin{array}{c}\text { National } \\
\text { Food Survey } \\
\text { (Defra 1942- } \\
\text { 1974) } \\
\text { "Household } \\
\text { consumption } \\
\text { of selected } \\
\text { foods from } \\
\text { 1942 to 2000" }\end{array}$ & $\begin{array}{l}\text { National Food Survey } \\
\text { Adjusted } \\
\text { (Defra 1974-2000) } \\
\text { "UK-household } \\
\text { purchases" }\end{array}$ & $\begin{array}{l}\text { Family Food Module } \\
\text { (Defra 2000-2018) } \\
\text { "UK-household } \\
\text { purchases" and “UK- } \\
\text { eating out purchases" }\end{array}$ & $\begin{array}{c}\text { FAO (1961-2018) } \\
\text { (food supply quantity) }\end{array}$ \\
\hline Poultry & Poultry & $\begin{array}{c}\text { Cooked poultry not } \\
\text { purchased in cans + } \\
\text { Chicken, uncooked - } \\
\text { whole chicken or chicken } \\
\text { pieces + Other poultry, } \\
\text { uncooked (including } \\
\text { frozen) }\end{array}$ & 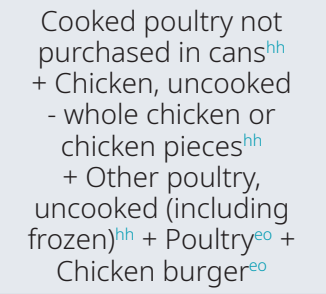 & Poultry Meat \\
\hline Fish & $\begin{array}{l}\text { Total fish and } \\
\text { fish products }\end{array}$ & Fish & $\begin{array}{c}\text { Fish }^{\text {hh }}+\text { Fish and fish } \\
\text { products }^{e 0}\end{array}$ & Fish, seafood (total) \\
\hline
\end{tabular}

converting to nutritional intake can be difficult (Serra-Majem et al., 2003). Whilst data on supply and purchases of selected macronutrients are provided by FAO-FBS and Defra-HBS, here we have compared data on food groups between the two data sources, as data on food supply and purchases have been used to assess how diets (Serra-Majem et al., 2003; Thar et al., 2020), and their associated health (Aiello et al., 2019) and environmental impacts (Lucas et al., 2021) have changed.

We fitted a linear model for FAO-FBS food supply against time (1961-2018) for all food types and calorie provision to analyse long term trends in the UK diet. We repeated this for Defra-HBS food purchases against time (1942-2018). Ruminant supply and purchases were calculated by summing supply and purchases of beef and mutton (lamb). Gradient of slope was compared between FAO-FBS and Defra-HBS (mean change, g/capita/day per year).

For each year (1961-2018) we calculated the difference between FAO-FBS food supply and Defra-HBS food purchases (as a percentage of Defra-HBS purchases) for each food type in turn. We explored whether this difference changed over time using correlation tests: Pearson's product-moment for normally distributed data, Spearman's rank for non-normally distributed data, after assessing for normality using Shapiro-Wilk. Finally, we estimated the mean difference between FAO-FBS food supply and Defra-HBS food purchases across all years for each food category.

\section{Results}

Differences between FAO-FBS and Defra-HBS in per capita quantities of food

Comparison of long-term data on UK food supply from FAO-FBS (1961-2018) and food purchases from Defra-HBS
(1942-2018) show many inconsistencies. Averaged across all years between 1961 and 2018 (1974-2018 for nuts and pulses), FAO-FBS food supply data reported significantly higher per capita outputs than Defra-HBS food purchases for meat and fish $(\mathrm{V}=0, \mathrm{n}=58, \mathrm{p}<0.001)$, dairy $(\mathrm{V}=1711, \mathrm{n}=58$, $\mathrm{p}<0.001)$ and calorie consumption $(\mathrm{V}=1711, \mathrm{n}=58, \mathrm{p}<0.001)$. On average, FAO-FBS meat and fish per capita outputs were $48 \%$ higher than Defra-HBS, FAO-FBS dairy per capita outputs were $24 \%$ higher than Defra-HBS and FAO-FBS calorie provision was $41 \%$ higher than Defra-HBS (Figure 2). This contrasts to nuts and pulses where FAO-FBS food supply was significantly lower $(44 \%)$ than Defra-HBS food purchases $(\mathrm{V}=0, \mathrm{n}=45, \mathrm{p}<0.001)$.

\section{Temporal trends: food type intake}

FAO-FBS and Defra-HBS datasets show different long-term trends in UK consumption (Table 3). Between 1961 and 2018, both data sources do show increasing intake of meat (FAO-FBS, +11.5\%; Defra-HBS, $+1.4 \%$ ) and decreasing intake of fish (FAO-FBS, $-3.3 \%$; Defra-HBS, $-3.2 \%$ ) and dairy (FAO-FBS, $-11.2 \%$; Defra-HBS, $-22.4 \%$ ) though the magnitude of change generally differs substantially. However, FAO-FBS shows an increase in calorie consumption (1961-2018, +3.5\%) while Defra-HBS records a decrease (1961-2018, -17.3\%). Per capita supply of nuts and pulses and calorie provision show a clear increasing trend when based on FAO-FBS, while the purchase data from Defra-HBS show a stable per capita purchase pattern (Figure 2 and Table 2).

Disaggregating total meat and fish by individual meat type, gives further detail on the different trends in supply and purchases. According to FAO-FBS, total meat consumption increased by $11.5 \%$ between 1961 and 2018 and decreased by $5.2 \%$ between 2008 and 2018; Defra-HBS estimated a $1.4 \%$ increase and a $3 \%$ decrease respectively. FAO-FBS 
FAO
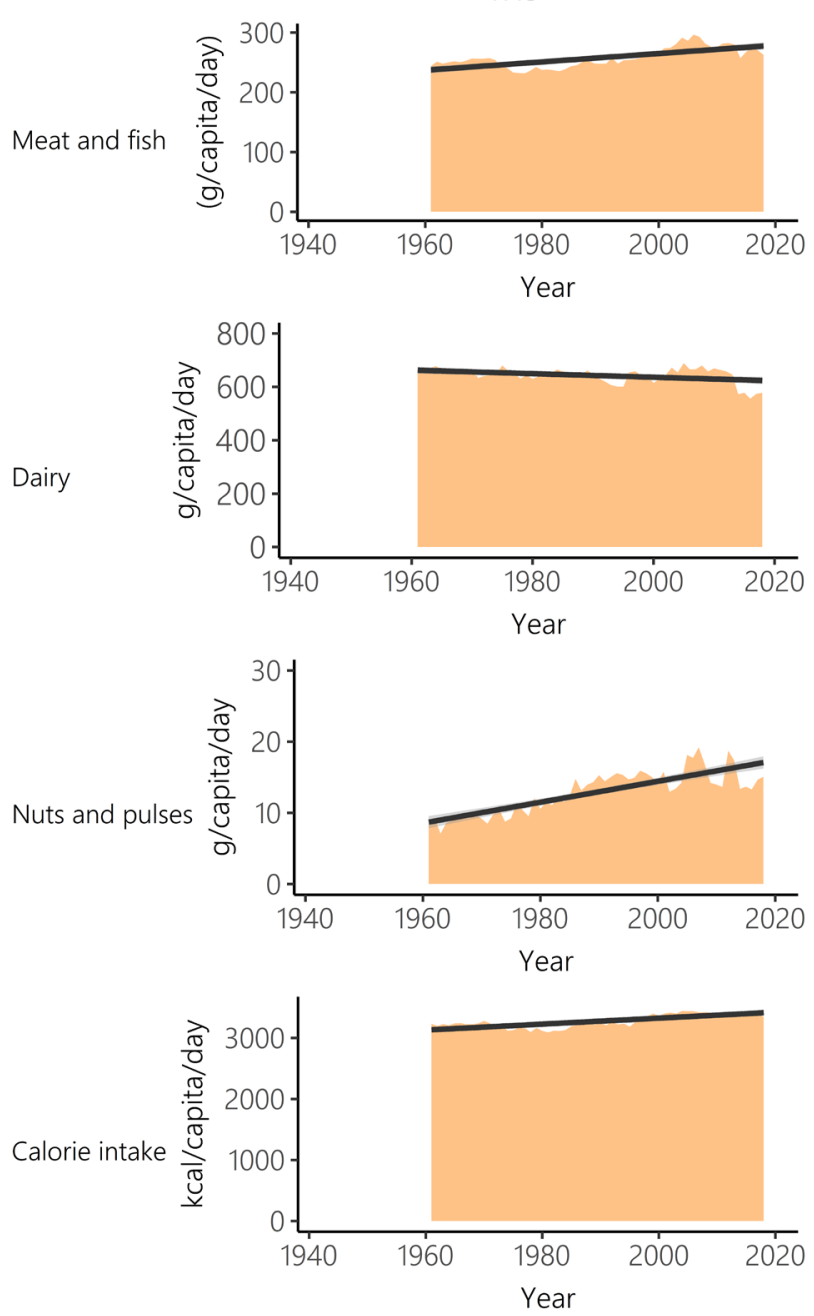
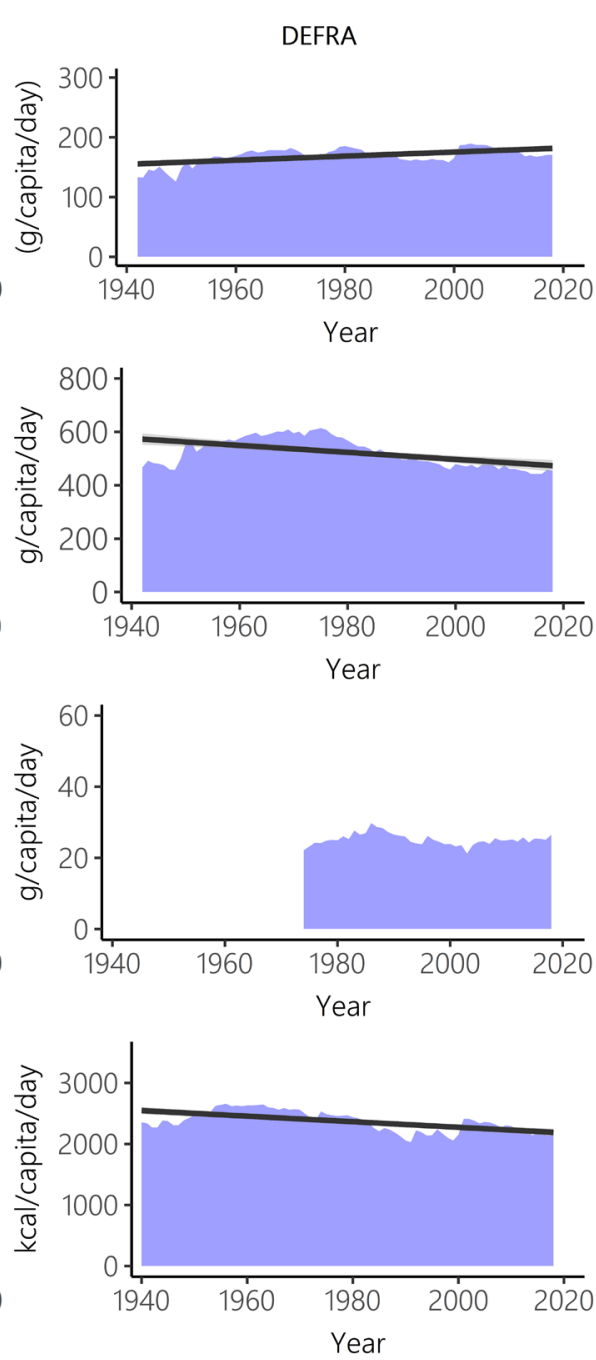

Figure 2. Meat and fish, dairy, nuts and pulses, and calorie intake over time for Food and Agriculture Organisation food balance sheets (FAO-FBS) food supply (orange) and Defra-household budget surveys (Defra-HBS) food purchases (blue). Linear model of supply/purchases over time (black) and 95\% confidence intervals (grey). In all cases, evaluation of assumptions through use of diagnostic plots indicated no violations.

estimated a $6.1 \%$ decrease in fish consumption between 1961 and 2018, and a 12.5\% decrease between 2008 and 2018; Defra-FBS estimated a $13.9 \%$ decrease for both time intervals (Table 2 and Table 3).

FAO-FBS and Defra-HBS both show a sharp decrease in ruminant intake and a steep increase in poultry consumption (Figure 3, Table 2 and Table 3). Pork and fish show more stable consumption over time. Between 1961 and 2018, Defra-HBS estimated steeper falls in ruminant and pork consumption than FAO-FBS (ruminant: FAO-FBS -39.7\%, Defra-HBS -67.4\%; pork: FAO-FBS -4.3\%, Defra-HBS $-11.2 \%$ ), and a smaller increase in poultry consumption (FAO-FBS, +381.4\%; Defra-HBS +227.8\%, Table 3). However, these results for ruminants, pork and poultry should be interpreted cautiously, as the Defra-HBS categorisations did not allow the total intake of these meat types to be calculated (for example, takeaways and meat pies could not be assigned), unlike FAO-FBS data (Table 1).

\section{Temporal trends: differences between FAO-FBS and Defra-HBS}

While a difference between supply and purchase data is to be expected, the difference between FAO-FBS food supply and Defra-HBS food purchases increased between 1961 and 2018 (Figure 4). for all food types (other than nuts and pulses), and for calorie intake. For nuts and pulses there was again a positive relationship between the difference between FAO-FBS food supply and Defra-HBS food purchases and time, but as FAO-FBS supply of nuts and pulses was lower than Defra-HBS purchases at the start of the timeseries, FAO-FBS supply and Defra-HBS purchases converged over time. When disaggregated by individual meat types, the difference between FAO-FBS and Defra-HBS increased over time for 
Table 2. Linear model outputs of FAO-FBS (Food and Agriculture Organisation food balance sheets) food supply (1961-2018) and Defra-HBS (household budget surveys) food purchases (1942-2018) against time for all food types and calories.

\begin{tabular}{|c|c|c|c|c|}
\hline & \multicolumn{2}{|c|}{ FAO-FBS food supply (1961-2018) } & \multicolumn{2}{|c|}{ Defra-HBS food purchases (1942-2018) } \\
\hline Food type & p value & $\begin{array}{c}\text { mean change (g/capita/day } \\
\text { per year) }\end{array}$ & $p$ value & mean change (g/capita/day per year) \\
\hline Meat and fish & $<0.001$ & 0.70 & $<0.001$ & 0.34 \\
\hline Dairy & $<0.001$ & -0.67 & $<0.001$ & -1.31 \\
\hline Nuts and pulses & $<0.001$ & 0.12 & $>0.05$ & -0.02 \\
\hline Calories & $<0.001$ & 4.89 (kcal/capita/day per year) & $<0.001$ & -4.56 (kcal/capita/day per year) \\
\hline Ruminant & $<0.001$ & -0.66 & $<0.001$ & -0.59 \\
\hline Pork & $<0.001$ & -0.11 & $<0.001$ & $<0.01$ \\
\hline Poultry & $<0.001$ & 1.42 & $<0.001$ & 0.59 \\
\hline Fish & $>0.05$ & 0.04 & $<0.001$ & $<0.01$ \\
\hline
\end{tabular}

Table 3. Intake of different food types every 10 years for FAO-FBS (Food and Agriculture Organisation food balance sheets) and Defra-HBS (household budget surveys). All units are grams/capita/day, except for calories which is kcal/capita/ day. Ruminant, pork and poultry do not sum to Total Meat because of a) other meat such as game and b) unidentified meat reported in Defra-HBS, e.g. meat pies.

\begin{tabular}{|c|c|c|c|c|c|c|c|c|c|c|}
\hline Food type & $\begin{array}{c}\text { Data } \\
\text { Source }\end{array}$ & 1961 & 1968 & 1978 & 1988 & 1998 & 2008 & 2018 & $\begin{array}{c}\text { Change between } \\
1961 \text { and } 2018 \text { in } \\
\text { grams (\%) }\end{array}$ & $\begin{array}{c}\text { Change between } \\
2008 \text { and } 2018 \text { in } \\
\text { grams (\%) }\end{array}$ \\
\hline \multirow{2}{*}{$\begin{array}{l}\text { Total meat } \\
\text { and fish }\end{array}$} & FAO-FBS & 244 & 256.7 & 236.2 & 252.7 & 262.2 & 281.6 & 262.6 & $18.6(7.6 \%)$ & $-19(-6.7 \%)$ \\
\hline & Defra-HBS & 171.8 & 178.9 & 177.6 & 172.4 & 161.9 & 178.5 & 170.7 & $-1.1(-0.6 \%)$ & $-7.8(-4.4 \%)$ \\
\hline \multirow{2}{*}{ Total fish } & FAO-FBS & 54.3 & 59.9 & 44.3 & 51.5 & 53.2 & 58.3 & 51.0 & $-3.3(-6.1 \%)$ & $-7.3(-12.5 \%)$ \\
\hline & Defra-HBS & 23 & 23.0 & 17.4 & 20.8 & 21.1 & 23.0 & 19.8 & $-3.2(-13.9 \%)$ & $-3.2(-13.9 \%)$ \\
\hline \multirow{2}{*}{ Total meat } & FAO-FBS & 189.7 & 189.7 & 196.8 & 191.9 & 201.2 & 209 & 223.3 & $21.9(11.5 \%)$ & $-11.7(-5.2 \%)$ \\
\hline & Defra-HBS & 148.8 & 148.8 & 155.9 & 160.2 & 151.6 & 140.8 & 155.5 & $2.1(1.4 \%)$ & $-4.6(-3 \%)$ \\
\hline \multirow{2}{*}{ Ruminant } & $F A O-F B S$ & 99.9 & 93.1 & 85.2 & 78.0 & 62.8 & 73.1 & 60.2 & $-39.7(-39.7 \%)$ & $-12.9(-17.6 \%)$ \\
\hline & Defra-HBS & 64.1 & 54.6 & 53.7 & 40.4 & 25.1 & 24.4 & 20.9 & $-43.2(-67.4 \%)$ & $-3.5(-14.3 \%)$ \\
\hline \multirow{2}{*}{ Pork } & FAO-FBS & 69.3 & 74.4 & 71.2 & 71.2 & 67.9 & 71.5 & 66.3 & $-3(-4.3 \%)$ & $-5.2(-7.3 \%)$ \\
\hline & Defra-HBS & 32.9 & 34.9 & 44.2 & 37.3 & 34.4 & 32.5 & 29.2 & $-3.7(-11.2 \%)$ & $-3.3(-10.2 \%)$ \\
\hline \multirow{2}{*}{ Poultry } & $F A O-F B S$ & 17.2 & 26.8 & 34.7 & 51.6 & 77.9 & 77.1 & 82.8 & 65.6 (381.4\%) & $5.7(7.4 \%)$ \\
\hline & Defra-HBS & 9.9 & 19.4 & 22.4 & 29.6 & 33.2 & 38.2 & 37.4 & 27.5 (277.8\%) & $-0.8(-2.1 \%)$ \\
\hline \multirow{2}{*}{ Dairy } & FAO-FBS & 651.3 & 652.8 & 631.5 & 639.1 & 642.2 & 680.3 & 578.1 & $-73.2(-11.2 \%)$ & $-102.2(-15 \%)$ \\
\hline & Defra-HBS & 584.2 & 599.9 & 580.7 & 520.4 & 465.5 & 459.5 & 453.2 & $-131(-22.4 \%)$ & $-6.3(-1.4 \%)$ \\
\hline \multirow{2}{*}{$\begin{array}{l}\text { Nuts and } \\
\text { pulses }\end{array}$} & FAO-FBS & 8.5 & 9.8 & 9.5 & 13.9 & 15.6 & 16.8 & 15.1 & $6.6(77.6 \%)$ & $-1.7(-10.1 \%)$ \\
\hline & Defra-HBS & NA & NA & 24.8 & 28.4 & 24.5 & 25.5 & 26.5 & NA & $1(3.9 \%)$ \\
\hline \multirow{2}{*}{ Calories } & FAO-FBS & 3231 & 3223 & 3095 & 3248 & 3352 & 3422 & 3344 & $113(3.5 \%)$ & $-78(-2.3 \%)$ \\
\hline & Defra-HBS & 2630 & 2560 & 2465 & 2188 & 2101 & 2276 & 2175 & $-455(-17.3 \%)$ & $-101(-4.4 \%)$ \\
\hline
\end{tabular}



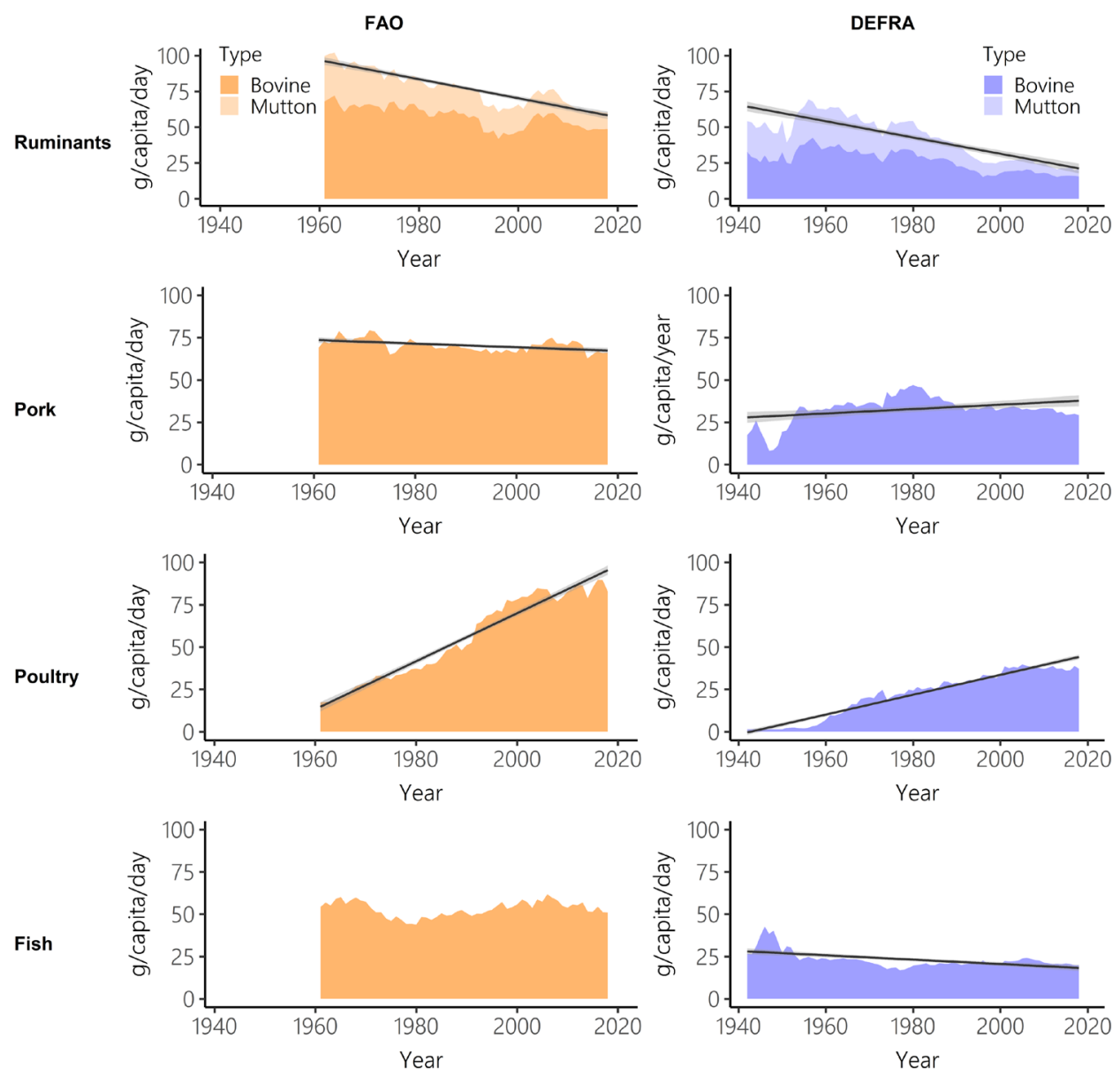

Figure 3. Ruminant, pork, poultry and fish intake over time for Food and Agriculture Organisation food balance sheets (FAOFBS) food supply (orange) and Defra household budget surveys (Defra-HBS) food purchases (blue). Linear model of supply/ purchases over time (black) and 95\% confidence intervals (grey). In all cases, evaluation of assumptions through use of diagnostic plots indicated no violations.

all meat types (ruminants, pork and poultry), but not for fish, which showed no change over time.

\section{Discussion}

The per capita quantities of food supplied in the UK (as reported by FAO-FBS) and purchased (as reported by Defra-HBS) are significantly different for all food types and for calorie consumption. This difference is greatest for meat and fish, where, on average, FAO-FBS are $48 \%$ greater than Defra-HBS. These differences affected the long-term trends in food consumption observed in the UK, as trends in consumption of nuts and pulses and calorie intake did not agree between FAO-FBS and Defra-HBS, and while the trends in meat and fish and dairy consumption did agree, the slope of the trends differed between the two data sources. The difference between FAO-FBS and Defra-HBS was not constant over time, and for all food types and calorie intake (other than nuts and pulses and fish) FAO-FBS and Defra-HBS values diverged between 1961 and 2018.
Our finding that FAO-FBS estimate higher consumption than Defra-HBS is consistent with similar studies within Europe (Naska et al., 2009; Serra-Majem et al., 2003) and across the world (Del Gobbo et al., 2015; Grünberger, 2014; Serra-Majem et al., 2003). For example Serra-Majem et al. (2003) found that FBS overestimate HBS meat consumption by $48 \%$ and dairy consumption by $33 \%$. Del Gobbo et al. (2015) found that FBS overestimate individual-based Global Dietary Database national dietary intake estimates of meat consumption by $120 \%$ and dairy consumption by $173 \%$. While Serra-Majem et al. (2003) found that FBS also overestimate HBS nuts and oil seed consumption by $183 \%$, Del Gobbo et al. (2015) found that FBS consumption of nuts and seeds were $27 \%$ lower than found from dietary surveys, in agreement with our findings. Del Gobbo et al. (2015) suggest this could be due to home or local production, or other food sources not captured by FAO-FBS. Rate of underreporting may not be consistent between food types (Mendez et al., 2004) and could be responsible for differences in the extent 

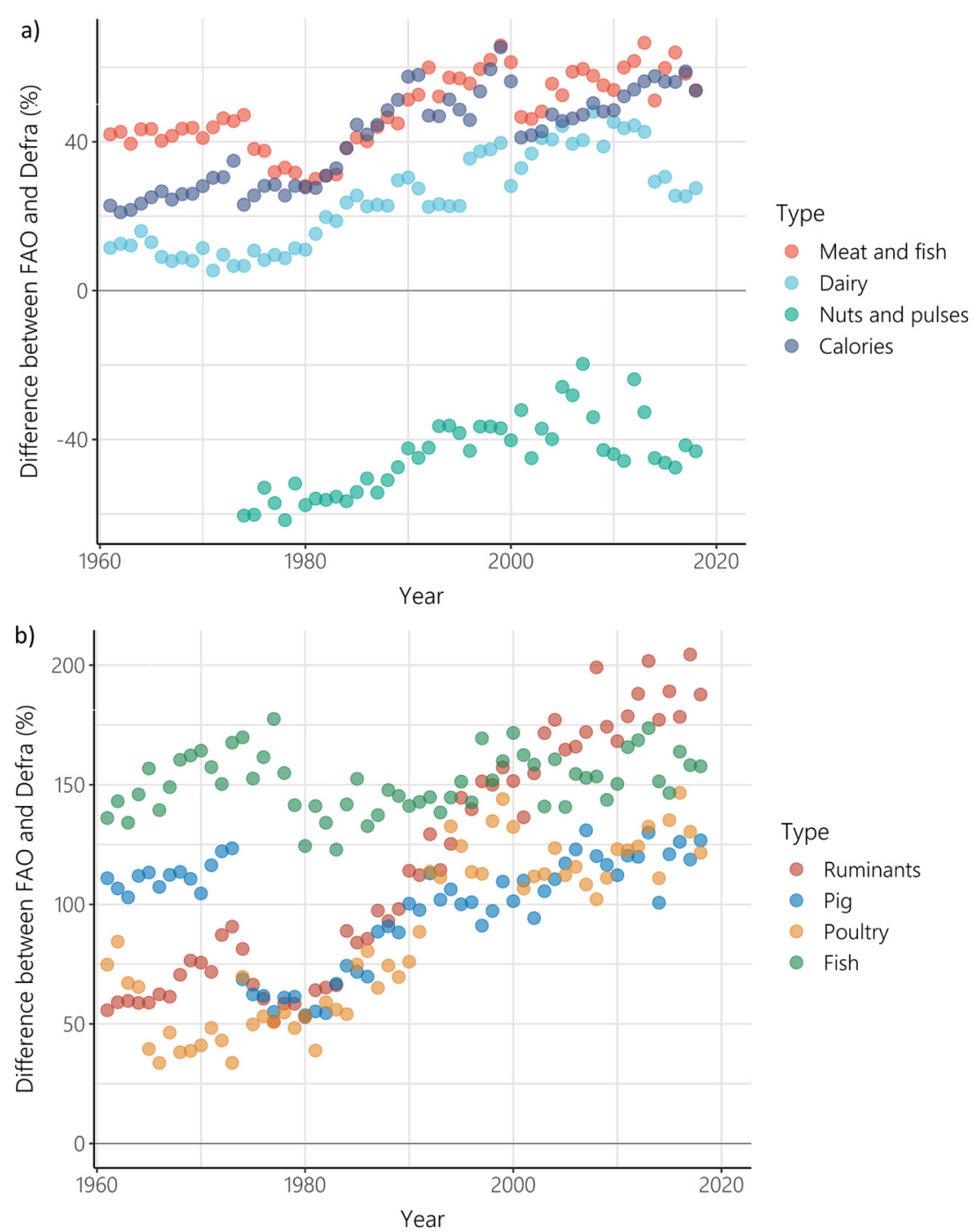

Figure 4. Difference between Food and Agriculture Organisation- food balance sheets (FAO-FBS) food supply and Defra- household budget surveys (Defra-HBS) food purchases between 1961 and 2018 for $\mathbf{a})$ meat and fish $(p<0.001, r=0.72$, number of years $=58)$, dairy $(p<0.001$, $\rho=0.84$, number of years $=58)$, nuts and pulses $(p<0.001, r=0.69$, number of years $=45)$ and calorie provision $(p<0.001, \rho=0.85$, number of years $=58)$, and $\mathbf{b})$ ruminants $(p<0.001, \rho=0.93$, number of years $=58)$, pork $(p<0.01, \rho=0.37$, number of years $=58)$, poultry $(p<0.001$, $\rho=0.82$, number of years $=58)$, and fish $(p>0.05, r=0.22$, number of years $=58)$. Differences greater than 0 indicate that FAO-FBS had higher per capita outputs than Defra-HBS.

of disparity observed between FAO-FBS and Defra-HBS. Hirvonen et al. (1997) showed that overreporting of 'healthy' foods occurs, perhaps partly explaining the overprediction of nuts and pulses by Defra-HBS relative to FAO-FBS.

The differences between reported consumption by FAO-FBS and Defra-HBS could be due to genuine differences in supply and purchases of food, or inaccuracies in data collection. FAO-FBS food supply estimates include retail food waste (Poore \& Nemecek, 2018), whereas Defra-HBS food purchases do not, so some of the observed differences could be due to retail food waste. If so, we would expect greater discrepancies in food with a short shelf-life (Parfitt et al., 2010). However, while meat, fish and dairy usually have a shorter shelf life than nuts and pulses (Premavalli, 2000), the latter exhibit a greater difference between mean FAO-FBS food supply and mean Defra-HBS food purchases. It seems likely that inaccuracies in data collection, primarily due to under-reporting, are also important. The National Food and Dietary Survey (a HBS similar to Defra's but run by Public Health England and the UK Food Standards Agency; Public Health England, 2020) has been shown to underestimate calorie consumption. Reported energy intake was shown to be $34 \%$ less than energy expenditure (measured using 
doubly labelled water), giving an indication of substantial under-reporting in the National Food and Dietary Survey (Office for National Statistics, 2016). A similar level of under-reporting in Defra surveys would account for most of the difference seen between FAO-FBS and Defra-HBS data.

As well as differences in estimates of overall per capita consumption we found no agreement between trends over time in FAO-FBS food supply and Defra-HBS food purchases of calories and nuts and pulses. As such, drawing conclusions about changes in the quantity of these foods consumed is challenging. Quantification of under-reporting and household and retail waste might reveal whether the divergence between FAO-FBS and Defra-HBS-based estimates are due to genuine divergences in supply and purchases or inaccuracies in data collection. Retail waste increased by $6 \%$ between 2015 and 2018 (WRAP, 2020), yet only represented $2.4 \%$ of post farm waste in 2015 (British Retail Consortium, 2016). Data on long-term trends on UK retail waste are limited. Harper \& Hallsworth (2015) suggest that under-reporting has increased over time and is responsible for falling calorie intake over time. They propose that increasing obesity levels, increase in desire to lose weight, increased eating outside the home and snacking, falling response rates of surveys and growing disparities between reference data and true portion sizes or food energy density, are responsible for the increase in under-reporting. Here we show that increase in under-reporting may not be limited to calorie intake, as trends in calorie intake differences between FAO-FBS and Defra-HBS are comparable to those of meat and fish, and dairy. These results suggest that the composition of the UK diet should be informed by both FAO-FBS and Defra-HBS data, with knowledge of their limitations.

Stewart et al. (2021) found that according to the National Diet and Nutrition Survey (NDNS), meat consumption in the UK declined by $17.4 \%$ (103.7g to $86.3 \mathrm{~g}$ ) between $2008 / 9$ and $2018 / 19$. This is a smaller quantity of meat and a larger decline than the trend we observed from Defra-HBS $3.0 \%$ decline in meat intake $(155.5 \mathrm{~g}$ to $150.9 \mathrm{~g}$ ) between 2008 and 2018) and FAO-FBS (5.2\% decline in meat intake $(223.3 \mathrm{~g}$ to 211.6g) between 2008 and 2018). Both NDNS and Defra-HBS are likely to be subject to under-reporting, unlike FAO-FBS (Office for National Statistics, 2016). Defra-HBS includes household food waste (as food purchases are measured) and NDNS does not (as food consumption is measured). However, if household food waste were the only discrepancy between the two datasets, this would indicate $42.8 \%$ of purchased meat in UK households is wasted (2018: $(150.9-86.3) / 150.9=42.8 \%)$, which is substantially higher than the estimated figure for meat and fish household waste of $21 \%$ ( $13 . \%$ avoidable (for example, not used in time) and $7.6 \%$ unavoidable (for example, bones and fish heads)) (Quested et al., 2013; Quested \& Murphy, 2014). This suggests methodology discrepancies are also contributing to this difference.

Defra-HBS estimated steeper falls in ruminant and pork consumption than FAO-FBS and a smaller increase in poultry consumption. It is key to be able to compare consumption of different meat types, given the higher environmental impacts of beef compared to chicken (Poore \& Nemecek, 2018) and the increased disease burden from increased red and processed meat consumption (Chung et al., 2021). While this is straightforward for FAO-FBS, it is hard to accurately sum up for the Defra-HBS data due to categories such as meat pies, ready meals and burgers and "takeaway miscellaneous meats".

For all food types except nuts and pulses (where the difference over time decreased), the difference between FAO-FBS and Defra-HBS increased between 1961 and 2018. With limited long-term data on the prevalence of under-reporting and extent of waste (FAO, 2001) identifying reasons for this divergence is challenging. To our knowledge, the increasing difference between FAO-FBS food supply and Defra-HBS food purchases has not been documented before. Due to the problems the divergence between these datasets poses for accurate monitoring of UK dietary change, identifying the reasons for this is an important topic for future research.

Studying the temporal aspect of discrepancies between FAO-FBS and Defra-HBS was a strength of this study. Here we show that the increasing disparity between FBS and HBS in calorie intake found by Harper \& Hallsworth (2015) over time is also present for specific food types. A limitation of this study was that we did not quantify the relative contribution of underreporting, retail waste and other differences in data collection methods to the reported discrepancies. This means that the extent to which inconsistencies are attributable to a genuine difference between supply and purchases, or inaccuracies in data collection, processing, and reporting is unknown. Understanding the reasons for discrepancies between FAO-FBS and Defra-HBS reported here, is important for resolving data inaccuracies and improving consistency of dietary monitoring in the UK. Exploration of whether such inconsistencies are also present for macronutrients such as protein and fat may be informative, and yield implications for monitoring progress towards healthier diets.

Efforts to make food systems healthier and more sustainable rely on routinely collected data such as FAO-FBS and Defra-HBS (Marshall et al., 2021). The inconsistencies between these datasets - and the challenges in directly comparing them - raises concerns for evidence-based policy making. The National Food Strategy (Dimbleby, 2020) recommends creation of a National Food System data programme to monitor and shape progress towards a better food system. While the envisaged collection of data on land use, retail and environmental and health impacts of food outlined in the National Food Strategy will be a vital resource to solve problems in the UK food system, these efforts may be undermined by the inconsistencies between datasets used to monitor UK food supply and purchases, outlined here. High quality surveys are most common in high income countries such as the UK. If these data inconsistencies exist in the UK, they are likely to exist in other countries as 
well, as exemplified by Del Gobbo et al. (2015), Grünberger (2014) and Serra-Majem et al. (2003). This raises the question as to whether other methods of data collection are needed for monitoring progress of food systems towards health and sustainability goals, and how inconsistencies in long-term dietary datasets can be reconciled.

\section{Concluding remarks}

Data produced on food supply by FAO-FBS and on food purchases by Defra-HBS differ for all food types and for calories, both overall and in terms of temporal trends. The difference between FAO-FBS and Defra-HBS increased over the time period studied, raising questions about the reliability of both data sources for monitoring dietary change, especially when used as routine data sources for evidence-based decision-making. Further research concerning the reasons for disagreement between FAO-FBS and Defra-HBS is required.

\section{Data availability}

Underlying data

University of Cambridge Repository: Research data supporting "Discrepancies between two long-term dietary datasets in the United Kingdom (UK)". https://doi.org/10.17863/ CAM.78207 (Smith et al., 2021).

- DataFrom_Figures_2_3_4_Tables_2_3.xlsx

- Household consumption of selected foods from 1942 to 2000 - 1942-2000.csv

- Household nutrient data from 1940 to 2000 - 1940-2000.csv

- UK - eating out purchases.ods

- UK - household and eating out nutrient intakes.ods

- UK - household purchases.ods

Data are available under the terms of the Creative Commons Attribution 4.0 International license (CC-BY 4.0).

\section{Source data}

\section{FAO-FBS data}

Data for between 1961 and 2018 are available from FAOSTAT and were first downloaded on 08/01/2020 from http://www.fao. org/faostat/en/\#data/FBSH titled 'Food Balances (-2013, old methodology and population)'.

- Data on food supply was downloaded by selecting 'United Kingdom of Great Britain and Northern
Ireand' from 'Countries' and 'Food supply quantity (kg/capita/yr)' from 'Elements' between 1961 and 2013 for the items listed in Table 1.

- Data on calorie supply was downloaded by selecting 'United Kingdom of Great Britain and Northern Ireand' from 'Countries', 'Food supply quantity (kcal/capita/day)' from 'Elements', and 'Grand Total + (Total) from 'Items (aggregated)' between 1961 and 2013.

Data for between 2014 and 2018 are available from FAOSTAT and were first downloaded on 24/10/2021 from https://www. fao.org/faostat/en/\#data/FBS titled 'Food Balances (2014-)'.

- Data on food supply was downloaded by selecting 'United Kingdom of Great Britain and Northern Ireand' from 'Countries' and 'Food supply quantity ( $\mathrm{kg} / \mathrm{capital}$ $y r)$ ' from 'Elements' between 2014 and 2018 for the items listed in Table 1.

- Data on calorie supply was downloaded by selecting 'United Kingdom of Great Britain and Northern Ireand' from 'Countries', 'Food supply quantity (kcal/capita/day)' from 'Elements', and 'Grand Total + (Total)' from 'Items (aggregated)' between 2014 and 2018.

Data are available under the terms of the Creative Commons Attribution-NonCommercial-ShareAlike 3.0 IGO (CC BY-NC- SA 3.0 IGO).

\section{Defra-HBS data}

Family Food Module data and adjusted National Food Survey data were first downloaded on 19/02/2020 from https://www.gov. uk/government/statistical-data-sets/family-food-datasets.

- Datasets are named 'UK - household purchases', 'UK eating out purchases' and 'UK - household and eating out nutrient intakes'.

National Food Survey data were downloaded on 08/01/2020 from https://webarchive.nationalarchives.gov.uk/20130103024837/ http://www.defra.gov.uk/statistics/foodfarm/food/familyfood/ nationalfoodsurvey/.

- National Food Survey data are named 'Household nutrientdatafrom 1940 to 2000-1940-2000' and 'Household consumption of selected foods from 1942 to 2000 - 19422000'.

Data are available under the terms of the Open Government Licence v3.0.
Aiello LM, Schifanella R, Quercia D, et al.: Large-scale and high-resolution analysis of food purchases and health outcomes. EPJ Data SCi. 2019; 8(1): 14.

Publisher Full Text

Balanza R, García-Lorda P, Pérez-Rodrigo C, et al.: Trends in food availability determined by the Food and Agriculture Organization's food balance sheets in Mediterranean Europe in comparison with other European areas. Public Health Nutr. 2007; 10(2): 168-176. PubMed Abstract | Publisher Full Text Bandy L, Adhikari V, Jebb S, et al.: The use of commercial food purchase data 
for public health nutrition research: A systematic review. PLOS One. 2019; 14(1): e0210192.

PubMed Abstract | Publisher Full Text | Free Full Text

Benthem de Grave R, Rust NA, Reynolds CJ, et al.: A catalogue of UK

household datasets to monitor transitions to sustainable diets. Glob Food Sec. 2020; 24: 100344.

Publisher Full Text

British Nutrition Foundation: Protein. British Nutrition Foundation, 2018.

Reference Source

British Retail Consortium: The Retail Industry's Contribution to Reducing

Food Waste. British Retail Consortium. 2016.

Reference Source

Chung MG, Li Y, Liu J: Global red and processed meat trade and non-

communicable diseases. BMJ Glob Health. 2021; 6(11): e006394.

PubMed Abstract | Publisher Full Text | Free Full Text

Cziszter LT, Acatincăi S, Neciu F, et al.: The Influence of Season on the Cow Milk Quantity, Quality and Hygiene. Scientific Papers: Animal Science and

Biotechnologies. 2012; 45(2)

Reference Source

De Keyzer W, Bracke T, McNaughton SA, et al.: Cross-Continental Comparison of National Food Consumption Survey Methods--A Narrative Review.

Nutrients. 2015; 7(5): 3587-3620.

PubMed Abstract | Publisher Full Text | Free Full Text

Defra: About Family Food. Defra, 2011.

Reference Source

Defra: Survey sampling for Family Food. Defra, 2012.

Reference Source

Del Gobbo LC, Khatibzadeh S, Imamura F, et al.: Assessing global dietary

habits: a comparison of national estimates from the FAO and the Global

Dietary Database. Am J Clin Nutr. 2015; 101(5): 1038-46.

PubMed Abstract | Publisher Full Text | Free Full Tex

Dimbleby H: The National Food Strategy - The Plan. The National Food Strategy, 2020.

Reference Sourc

FAO: Technical Conversion Factors for Agricultural Commodities. Food and Agriculture Organisation of the United Nations, 2000

Reference Source

FAO: Food Balance Sheets: A handbook. Food and Agriculture Organisation of the United Nations, 2001

Reference Source

FAO: New Food Balances: Description of utilization variables. FAO, 2017.

Reference Source

FAO: Key differences between new and old Food Balance Sheet (FBS)

methodology. FAO, 2020.

Reference Source

Grünberger K: Estimating Food Consumption Patterns by Reconciling Food

Balance Sheets and Household Budget Surveys. FAO, 2014; 1014-1960.

Reference Source

Harper $\mathrm{H}$, Hallsworth M: Counting Calories How under-reporting can explain the apparent fall in calorie intake. Behavioural Insights Ltd, 2015.

Reference Source

Hirvonen T, Männistö S, Roos E, et al.: Increasing prevalence of

underreporting does not necessarily distort dietary surveys. Eur J Clin Nutr.

1997: 51(5): 297-301.

PubMed Abstract | Publisher Full Text

Lucas E, Galán-Martín Á, Pozo C, et al.: Global environmental and nutritional assessment of national food supply patterns: Insights from a data

envelopment analysis approach. Sci Total Environ. 2021; 755(Pt 1): 142826.

PubMed Abstract | Publisher Full Text

Marshall Q, Bellows AL, McLaren R, et al.: You Say You Want a Data

Revolution? Taking on Food Systems Accountability. Agriculture. 2021; 11(5):

422

Publisher Full Text

Mendez MA, Wynter S, Wilks R, et al.: Under- and overreporting of energy is related to obesity, lifestyle factors and food group intakes in Jamaican adults. Public Health Nutr. 2004; 7(1): 9-19.

PubMed Abstract | Publisher Full Text
Naska A, Berg MA, Cuadrado C, et al.: Food balance sheet and household budget survey dietary data and mortality patterns in Europe. $\mathrm{Br} J$ Nutr. 2009; 102(1): 166-171.

PubMed Abstract | Publisher Full Text

Office for National Statistics: A Government Statistical Service perspective on official estimates of calorie consumption. Office for National Statistics, 2016.

Reference Source

Parfitt J, Barthel M, Macnaughton S: Food waste within food supply chains: quantification and potential for change to 2050. Philos Trans $R$ Soc Lond $B$ Biol Sci. 2010; 365(1554): 3065-3081.

PubMed Abstract | Publisher Full Text | Free Full Text

Peng CJ, Lin CY, Guo HR: A Comparison of Food Supply from 1984 to 2009 and Degree of Dietary Westernization in Taiwan with Asian Countries and World Continents. Biomed Res Int. 2015; 2015: 628586.

PubMed Abstract | Publisher Full Text | Free Full Text

Perignon M, Vieux F, Soler LG, et al.: Improving diet sustainability through evolution of food choices: review of epidemiological studies on the environmental impact of diets. Nutr Rev. 2017; 75(1): 2-17.

PubMed Abstract | Publisher Full Text | Free Full Text

Poore J, Nemecek T: Reducing food's environmental impacts through producers and consumers. Science. 2018; 360(6392): 987-992.

PubMed Abstract | Publisher Full Text

Premavalli KS: Convenience Foods for Defence Forces Based on Traditional Indian Foods. Defen Sci J. 2000; 50(4): 361-369.

Reference Source

Public Health England: National Diet and Nutrition Survey. Gov.UK, 2020

Reference Source

Quested T, Ingle R, Parry A: Household Food and Drink Waste in the United Kingdom 2012. In October (Issue November). 2013.

Reference Source

Quested T, Murphy L: Household food and drink waste: A product focus. (Issue October), 2014

Reference Source

R Core Team: R: A Language and Environment for Statistical Computing

R Foundation for Statistical Computing. 2020

Reference Source

Ritchie H, Roser M: Meat and Dairy Production. Our World in Data, 2020.

Reference Source

Serra-Majem L, MacLean D, Ribas L, et al.: Comparative analysis of nutrition data from national, household, and individual levels: results from a WHOCINDI collaborative project in Canada, Finland, Poland, and Spain.

J Epidemiol Community Health. 2003; 57(1): 74-80.

PubMed Abstract | Publisher Full Text | Free Full Text

Smith K, Scheelbeek P, Balmford A, et al.: Research data supporting

"Discrepancies between two long-term dietary datasets in the United

Kingdom (UK)". [Dataset]. 2021.

http://www.doi.org/10.17863/CAM.78207

Stewart C, Piernas C, Cook B, et al.: Trends in UK meat consumption: analysis of data from years 1-11 (2008-09 to 2018-19) of the National Diet and Nutrition Survey rolling programme. Lancet Planet Health. 2021; 5(10): E699-E708.

PubMed Abstract | Publisher Full Text | Free Full Text

Thar CM, Jackson R, Swinburn B, et al.: A review of the uses and reliability of food balance sheets in health research. Nutr Rev. 2020; 78(12): 989-1000. PubMed Abstract | Publisher Full Text

Whybrow S, Horgan GW, Macdiarmid JI: Buying less and wasting less food. Changes in household food energy purchases, energy intakes and energy density between 2007 and 2012 with and without adjustment for food waste. Public Health Nutr. 2017; 20(7): 1248-1256.

PubMed Abstract | Publisher Full Text

WRAP: Courtauld Commitment 2025 Milestone Progress Report. WRAP 2020 .

Reference Source

WRAP: Food surplus and waste in the UK - key facts. In Wrap (Issue October). 2021.

Reference Source 


\section{Open Peer Review}

\section{Current Peer Review Status:}

\section{Version 1}

Reviewer Report 24 June 2022

https://doi.org/10.21956/wellcomeopenres.19061.r50555

(C) 2022 West P. This is an open access peer review report distributed under the terms of the Creative Commons Attribution License, which permits unrestricted use, distribution, and reproduction in any medium, provided the original work is properly cited.

\section{Paul West}

${ }^{1}$ Institute on the Environment, University of Minnesota, Minneapolis, MN, USA

2 Project Drawdown, San Francisco, CA, USA

Smith and colleagues provide a solid analysis that compares the two main databases--FAO's Food Balance Sheets and DEFRA's Household Budget Surveys--for assessing dietary status and trends. The discrepancies, how the change over time, and potential sources of these discrepancies are well explained. Their results have important implications for assessing trends and setting sciencebased policies related to diet in the UK.

The paper is sufficient for indexing as it is at the time of my review (24 June 2022), but I think it can be improved by discussing the implications and recommendations. Here are a few examples of topics that would strengthen the discussion:

1. Is one of the databases better suited for some analyses than others? Is the FAO database better for assessing the environmental impacts of diet as it includes food waste? Is the HBS better suited for assessing connections between household-level choices and their relation to demographics and price changes?

2. Do you recommend that most analysis used for research or policy use both databases? If so, is one better in terms of totals (FAO if HBS under-reports??) and then use the relative trends in both databases to present a range? For example, it looks like FAO estimates of $\mathrm{g} / \mathrm{capita}$ /day of meat consumption are 2-3x estimates from HBS (Fig 3).

3. You mention that food waste explaining some of the difference in the values because it is embedded in the FAO data. But if $70 \%$ of the post farmgate waste in the UK is at the consumer stage, waste doesn't explain the much of differences in the databases, right?

4. What are ways to improve the data? What recommendations of either future changes in data collection or post processing (but still allow for consistency across the time series)? Could you get closer to the "truth" by adding a third data set, such as national-level sales data for foods like beef? 
5. In a few places in the paper, other studies are cited that noted that the differences in the databases "can be highly problematic" (Del Gobbo et al. 2015, Sarra-Majem et al. 2003). Did these authors address any of the above ideas related to implications or recommendations? If so, how does your analysis and assessment of implications compare? In other words, provide more detail than "it's problematic."

Minor point:

The Excel Version is noted as 2108, which I assume is meant to be 2018.

Is the work clearly and accurately presented and does it cite the current literature? Yes

Is the study design appropriate and is the work technically sound?

Yes

Are sufficient details of methods and analysis provided to allow replication by others? Yes

If applicable, is the statistical analysis and its interpretation appropriate? Yes

Are all the source data underlying the results available to ensure full reproducibility? Yes

Are the conclusions drawn adequately supported by the results? Yes

Competing Interests: No competing interests were disclosed.

Reviewer Expertise: food systems, ecosystems, global change

I confirm that I have read this submission and believe that I have an appropriate level of expertise to confirm that it is of an acceptable scientific standard.

Author Response 28 Aug 2022

Kerry Smith, University of Cambridge, Cambridge, UK

\section{Comment 1.}

Smith and colleagues provide a solid analysis that compares the two main databases--FAO's Food Balance Sheets and DEFRA's Household Budget Surveys--for assessing dietary status and trends. The discrepancies, how the change over time, and potential sources of these discrepancies are well explained. Their results have important implications for assessing trends and setting science-based policies related to diet in the UK.

The paper is sufficient for indexing as it is at the time of my review (24 June 2022), but I 
think it can be improved by discussing the implications and recommendations.

\section{Response 1.}

We are grateful to the reviewer for these positive comments, and for the suggestions on how to improve the discussion. We address the suggestions individually below.

\section{Comment 2.}

Here are a few examples of topics that would strengthen the discussion: Is one of the databases better suited for some analyses than others? Is the FAO database better for assessing the environmental impacts of diet as it includes food waste? Is the HBS better suited for assessing connections between household-level choices and their relation to demographics and price changes?

Do you recommend that most analysis used for research or policy use both databases? If so, is one better in terms of totals (FAO if HBS under-reports??) and then use the relative trends in both databases to present a range? For example, it looks like FAO estimates of $\mathrm{g}$ /capita/day of meat consumption are 2-3x estimates from HBS (Fig 3).

\section{Response 2.}

We thank the reviewer for the suggestions. We added the following paragraph to the discussion,

"With current data quality and availability, we recommend that where possible, both FAO-FBS and Defra-HBS are used in parallel to monitor dietary trends. For specific applications, use of one dataset may be appropriate. For example, when conducting assessments of the environmental impact of food consumption, the presence of underreporting in Defra-HBS risks underestimation of the environmental impact of UK food consumption. In contrast, food balance sheets (FAO-FBS) are not subject to underreporting, and are readily conciliable with major life cycle analyses datasets (Poore and Nemecek, 2018), so are best suited to this application. The inclusion of retail waste in FAO-FBS estimates impedes monitoring of purchasing patterns. Household budget surveys (Defra-HBS) monitor purchases directly, and are published alongside demographic data, so are appropriate for monitoring changes in purchasing patterns, and comparisons between demographic groups. Understanding dataset methodology and limitations supports decision making in UK dietary analyses, when identifying the most suitable dataset or datasets to use."

\section{Comment 3.}

You mention that food waste explaining some of the difference in the values because it is embedded in the FAO data. But if $70 \%$ of the post farmgate waste in the UK is at the consumer stage, waste doesn't explain the much of differences in the databases, right?

\section{Response 3.}

In agreement with the reviewer, we believe that waste doesn't explain much of the differences in the datasets, due to its small contribution to total post farm waste. As such we have edited the discussion accordingly, "Retail waste increased by 6\% between 2015 and 2018 (WRAP, 2020), yet only represented 2.4\% of post farm waste in 2015 (British Retail Consortium, 2016). Data on long-term trends on UK retail waste are limited, but given its small contribution to total post farm waste, it's unlikely waste is a major factor causing the divergence between FAO-FBS and Defra-HBS." 


\section{Comment 4.}

What are ways to improve the data? What recommendations of either future changes in data collection or post processing (but still allow for consistency across the time series)? Could you get closer to the "truth" by adding a third data set, such as national-level sales data for foods like beef?

\section{Response 4.}

We have added the following to the discussion.

"Analyses of UK dietary trends are impeded by the differences between FAO-FBS and Defra-HBS. One approach, used by Del Gobbo et al. (2015), is to apply calibration models to adjust FAO-FBS to dietary surveys. This assumes that dietary surveys provide an accurate estimation of consumption, which given the observed levels of underreporting in the National Food and Dietary Survey (Office for National Statistics, 2016), may not be the case. To improve understanding of UK dietary trends, monitoring of underreporting across time and food types is necessary. Additionally, data on the proportion of food wasted at each stage of the production chain, disaggregated by food type, would assist in reconciling differences between FAO-FBS and DefraHBS. If data collection on waste and underreporting were integrated into current data collection processes, and published alongside dietary datasets, this would allow uncertainties to be reduced, whilst retaining consistency in long term temporal monitoring. Improving data availability on waste and underreporting is key for enabling robust analyses of UK dietary change."

\section{Comment 5.}

In a few places in the paper, other studies are cited that noted that the differences in the databases "can be highly problematic" (Del Gobbo et al. 2015, Sarra-Majem et al. 2003). Did these authors address any of the above ideas related to implications or recommendations? If so, how does your analysis and assessment of implications compare? In other words, provide more detail than "it's problematic."

\section{Response 5.}

We expanded on the implications and recommendations made by other studies comparing food balance sheet and household budget surveys, in the introduction,

"Findings from studies outside the UK indicate that using only one of these methodologies to assess dietary trends can be highly problematic (Del Gobbo et al., 2015; Serra-Majem et al.. 2003), and hinders food policy planning, which requires accurate knowledge of food consumption patterns (Serra-Majem et al., 2003). Investigating the investigating reasons behind data discrepancies helps to understand their improves understanding of the limitations of these datasets (Benthem de Grave et al., 2020)."

We also added detail to the discussion.

"Analyses of UK dietary trends are impeded by the differences between FAO-FBS and Defra-HBS. One approach, used by Del Gobbo et al. (2015), is to apply calibration models to adjust FAO-FBS to dietary surveys. This assumes that dietary surveys provide an accurate estimation of consumption, which given the observed levels of underreporting in the National Food and Dietary Survey (Office for National Statistics, 2016), may not be the case. To improve understanding of UK dietary trends, monitoring of underreporting across time and food types is necessary."

\section{Comment 6.}


The Excel Version is noted as 2108, which I assume is meant to be 2018.

Response 6.

We have doubled checked the Excel Version number and it is supposed to be 2108.

Competing Interests: No competing interests were disclosed.

Reviewer Report 17 January 2022

https://doi.org/10.21956/wellcomeopenres.19061.r47702

(C) 2022 Marinova D. This is an open access peer review report distributed under the terms of the Creative Commons Attribution License, which permits unrestricted use, distribution, and reproduction in any medium, provided the original work is properly cited.

\section{Dora Marinova}

Curtin University Sustainability Policy (CUSP) Institute, Curtin University, Perth, WA, Australia

This is a very important and timely analysis. It also has been carried out in a competent manner. The conclusions that the authors draw are equally important.

Being the first paper that specifically tackles the differences between different databases and surveys, it also demonstrates the challenges that food supply and consumption face in terms of data collection and coverage.

I have no hesitation to recommend for this paper to be published. Below are some recommendations which I think will approve the readability of the paper for an international audience:

DEFRA stands for Department for Environment and Rural Affairs (which is not stated) and the acronym should be fully capitalised.

There are a couple of 2008-2018 decreasing trends for meat and fish in both databases. It would be good if they are also presented graphically.

The discussion section would benefit from some possible explanations for the discrepancies in nuts and legumes in the case of UK.

The conclusion section could be expanded to do justice to the study. For example, it is important to emphasise again the issue of waste. Highlights from the findings can also be included.

Some minor editorial comments - in academic writing sentences should not start with an acronym; the verb in relation to FAO should be used in singular referring to the organisation.

Is the work clearly and accurately presented and does it cite the current literature? 
Yes

Is the study design appropriate and is the work technically sound?

Yes

Are sufficient details of methods and analysis provided to allow replication by others? Yes

If applicable, is the statistical analysis and its interpretation appropriate?

Yes

Are all the source data underlying the results available to ensure full reproducibility? Yes

Are the conclusions drawn adequately supported by the results?

Yes

Competing Interests: No competing interests were disclosed.

Reviewer Expertise: sustainability, food systems

I confirm that I have read this submission and believe that I have an appropriate level of expertise to confirm that it is of an acceptable scientific standard.

Author Response 28 Aug 2022

Kerry Smith, University of Cambridge, Cambridge, UK

\section{Comment 1:}

This is a very important and timely analysis. It also has been carried out in a competent manner. The conclusions that the authors draw are equally important.

Being the first paper that specifically tackles the differences between different databases and surveys, it also demonstrates the challenges that food supply and consumption face in terms of data collection and coverage.

I have no hesitation to recommend for this paper to be published. Below are some recommendations which I think will approve the readability of the paper for an international audience.

Response 1:

We are grateful to the reviewer for their positive comments and recommendations. We address them individually below.

\section{Comment 2:}

DEFRA stands for Department for Environment and Rural Affairs (which is not stated) and the acronym should be fully capitalised.

Response 2:

We have added the full name for Defra in the abstract and in first use in the introduction. In the abstract, 
"We used UK longitudinal dietary data on food supply, provided by the Food and Agriculture Organisation (FAO) (FAO-FBS, 1961-2018), and food purchases, provided by the Department for Environment, Food and Rural Affairs (Defra) Defra (Defra-HBS, 1942-2018)."

In the introduction,

"Both food balance sheets (FBS) (published by Food and Agriculture Organisation (FAO), hereafter referred to as FAO-FBS) and household budget surveys (HBS) (published by the Department for Environment, Food and Rural Affairs (Defra) Defra in the United Kingdom (UK), hereafter referred to as Defra-HBS) have been used to approximate trends in consumption over time (for example Grünberger, 2014 and Peng et al., 2015)."

The UK government does not capitalise Defra so we have followed the same formatting.

\section{Comment 3:}

There are a couple of 2008-2018 decreasing trends for meat and fish in both databases. It would be good if they are also presented graphically.

\section{Response 3:}

We have added trend lines between 2008-2018 (where significant) to figure 2, and added a paragraph to explain these trends in the results.

"Long-term trends in consumption were not always representative of short-term trends (Figure 3, Tables 2 and 4). Between 2008 and 2018, both FAO-FBS and Defra-HBS estimated significant declines in meat consumption (FAO-FBS -5.2\%, Defra-HBS -3.0\%), in contrast to the significant increase estimated by both datasets over the whole time period (Table 3). Significant declines in dairy supply between 2008-2018 (-15.0\%) were estimated by FAO-FBS despite no significant trend between 1961 and 2018. No significant change in supply of nuts and pulses and calorie intake was estimated by FAO-FBS between 2008 and 2018, despite significant increases in supply between 1961 and 2018."

\section{Comment 4:}

The discussion section would benefit from some possible explanations for the discrepancies in nuts and legumes in the case of UK.

\section{Response 4:}

While we have provided some explanation for why the difference in estimations between FAO-FBS and Defra-HBS for nuts and pulses might differ from other food groups, we did not provide information on why FAO-FBS and Defra-HBS might be converging for nuts and pulses and not other food groups. As such, we have added the following to the discussion. "Nuts and pulses are an exception to the observed divergence, with FAO-FBS supply and DefraHBS purchases converging overtime. This could be due to an increase in home production of food since 1985 (Defra, 2021), or a decrease in under-reporting (for example due to the rise in awareness of the environmental benefit of switching to plant-based protein (Alae-Carew et al.. 2022))."

\section{Comment 5:}

The conclusion section could be expanded to do justice to the study. For example, it is important to emphasise again the issue of waste. Highlights from the findings can also be included. 


\section{Response 5:}

We have expanded the conclusions section as below.

"Data produced on food supply by FAO-FBS and on food purchases by Defra-HBS differ for all food types and for calories, both overall and in terms of temporal trends. Underreporting and retail waste were the main reasons for these differences, with underreporting expected to be the greatest contributor. Further research concerning the reasons for disagreement between FAO-FBS and Defra-HBS is required. Specifically, data collection on temporal trends in underreporting, and food waste at each stage of the production chain, disaggregated by food type, could assist in reconciling the differences between datasets.

We recommend that where possible assessments of dietary trends use both household budget surveys and food balance sheets in parallel, with knowledge of their limitations. For most food groups, the difference between FAO-FBS and Defra-HBS increased over time raising questions about the reliability of both data sources for monitoring dietary change, especially when used as routine data sources for evidence-based decision-making."

\section{Comment 6:}

Some minor editorial comments - in academic writing sentences should not start with an acronym; the verb in relation to FAO should be used in singular referring to the organisation.

\section{Response 6:}

Sentences starting with an acronym have been rearranged.

Competing Interests: No competing interests were disclosed. 